\title{
Groundwater and Poverty Reduction: Challenges and Opportunities for Sustainable Development in Nigeria
}

\author{
Dr. Nwankwoala H.O. \\ Department of Geology, University of Port Harcourt, Nigeria \\ Author email address: nwankwoala_ho@yahoo.com
}

ABSTRACT

\begin{abstract}
Water is essential for life and for most activities of human society. Both economic and social development and the maintenance of human health are completely dependent upon ready access to adequate water supplies. All societies require water both for basic survival and for economic development. Limited and inadequate access to water supply for productive uses such as livestock watering, crop irrigation, and small scale industries, constraints households and communities in a condition of vulnerability and poverty. Lack of access to safe domestic, and indeed to significant quantities of water for other productive uses defines and contributes to poverty. Provision of and access to safe domestic water for productive uses will contribute to the Millennium Development target of halving the proportion of people without access to safe and sustainable water supplies by 2015, in addition to contributing significantly to incomes and livelihoods. Groundwater resources thus offer major development of communities. Great socio-economic benefits have been generated by highquality, relatively low-cost, drought-resilient groundwater supplies for urban expansion, industrial enterprises and agricultural irrigation and with rising population and continuing development in Nigeria, demand for groundwater is still increasing. This paper, therefore opines that it is not simply a matter of having a low or irregular income, but of lacking a wider set of assets - human, social, physical, natural as well as financial and being vulnerable to changes which the less-poor can readily survive. This paper therefore aims at promoting water poverty to water prosperity, outlining and exploring the opportunities and role of groundwater in the reduction of chronic poverty, economic sustainability as well as draws out conclusion for the way forward in Nigeria. The contribution of groundwater to the enhancement of livelihood and in the fight to combat poverty, reduce vulnerability and improve chances of survival is advocated. Overall, groundwater is and will be a reliable water resource for human development for solving water supply issues, improvement in human health conditions and alleviation of poverty.
\end{abstract}

Keywords: Groundwater, poverty alleviation, sustainability, sustainable development, Nigeria

\section{INTRODUCTION}

Poverty is an unacceptable human condition that can and must be eliminated by public policy and action (Guntur, 2007). According to Ndem (2008), there is the need for poverty alleviation programmes to be implemented within the framework of economic growth with equity, sound economic management and good governance, among others. ADB (1979) states that individuals and societies are poor and tend to remain so if they are not empowered to participate in making the decisions that shape their lives. The Nigerian government at different times has been launching different poverty alleviation programmes at different times by different regimes of government, yet the outcome is always a deviation from expectations. The role of groundwater in poverty reduction and 
improvement of the situation in Nigeria is hereby advocated. The strong link between water provision and poverty alleviation has been highlighted in many studies (Sullivan 2002; Cohen and Sullivan 2010) though the causes of poverty and their relation to water are very complex (Molle and Mollinga 2003; Komnenic et al., 2009; Harrington et al., 2009).

Groundwater has emerged as the primary democratic water source and poverty reduction tool in Nigeria's rural areas. Groundwater is one of the Nigeria's most important natural resources and an important source of water for domestic supply and agriculture. On account of its near universal availability, dependability and low capital cost, it is the most preferred source of water to meet the requirements of various user sectors in Nigeria. Groundwater has made significant contributions to the growth of Nigeria's economy and has been an important catalyst for its socio-economic development. Its importance as a precious natural resource $\mathrm{n}$ the Nigerian context can be gauged from the fact that it accounts for more than 40 percent of the Nation's public water supply. In addition, more than 40 million people, including most of the rural population, supply their own drinking water from domestic wells. Groundwater is often called a 'hidden resource' because it cannot be seen in the same way as water in a river, lake or reservoir. The volumes of groundwater are large, however - it is estimated that there is about one hundred times fresher groundwater on earth than all the fresh water in rivers and lakes (Shiklomanov, 1998). As a result, groundwater is an important source of much of the water used for drinking and irrigation. It is the Nation's principal reserve of freshwater and represents much of the potential future water supply. Groundwater is a major contributor to flow in many streams and rivers and has a strong influence on river and wetland habitats for plants and animals.

Aside from the aforementioned, certain features make groundwater attractive as source of potable water supply. Firstly, there are aquifers in several parts of the country that can frequently be tapped at shallow depths close to the water demand centres in response to the dispersed nature of rural settlements. Secondly, water stored in aquifers is for most part protected naturally from evaporation and pollution, and well yields are in many cases adequate, offering water supply security in regions prone to protracted droughts as is common in the northern parts of Nigeria. Thirdly, with adequate aquifer protection, groundwater has excellent microbial and chemical quality, and requires minimal or no treatment at all. Fourthly, the capital cost of groundwater development as opposed to the conventional treatment of surface waters is relatively modest and the resource lends itself to flexible development, capable of being phased in with rising demand. Lastly, groundwater development is fast, does not require a large initial financial investment, delivers a better service to the people, steadily improves social welfare and is significantly less prone to corrupt practices. The overwhelming availability of groundwater resources globally, which are also naturally better protected against contamination, clearly indicates that the future of humanity is intimately linked to the quantity and quality of the world's groundwater resources.

Some of the benefits of groundwater development are linked to the inherent characteristics of groundwater resources: most aquifers provide large water storage space and help stabilize water supply during peak of dry season and droughts; the sluggish flow of groundwater through small voids helps in purifying water, necessitating lower or no treatment costs prior to its use as drinking water; the general availability of groundwater makes it a resource easy to access; and in areas of extensive aquifers groundwater development can increase recharge and also decrease flood intensity.

Poverty reduction is a serious matter that requires serious attention. No doubt, the Federal Government of Nigeria has at different times instituted different poverty alleviation programmes. Yet, evidence shows that poverty is still on the increase rather. Inadequate access to safe water for domestic purposes (drinking, cooking, personal and home hygiene) is an important measure of poverty (Carter and Bevan, 2008). Extending and enhancing the development of water resources in general, and of groundwater in particular, can have significant beneficial impacts on poverty and livelihoods. In this paper, it is advocated that clear and unambiguous identification of the role of groundwater in poverty reduction and directing such programmes will improve the situation in Nigeria.

\section{Groundwater Sustainability}

Sustainable groundwater resources development implies use of groundwater as a source of water supply, on a long term basis, in an efficient and equitable manner sustaining its quality and environmental diversity. An understanding of the behaviour of a groundwater system and of its interaction with the environment is required to formulate a sustainable management plan (Das and Puspa, 1997; Nwankwoala, 2011).

The sustainability of groundwater resources is a function of many factors, including decreases in groundwater storage, reductions in stream flow and lake levels, loss of wetland and riparian ecosystems, land subsidence, saltwater intrusion, and changes in groundwater quality. Each groundwater system and development situation is unique and requires an analysis adjusted to the nature of the water issues faced, including the social, economic, and legal constraints that must be taken into account. A key challenge for achieving groundwater sustainability is to frame the hydrologic implications of various alternative management strategies in such a way that they can be properly evaluated. "If sustainable development is to mean anything, such development must be based on an appropriate 
understanding of the environment-an environment where knowledge of water resources is basic to virtually all endeavors."

The concept 'sustainable development' was first coined in the 1980s and was promoted to a high level of international prominence in the report Our Common Future (WCED, 1987), known as the Brundtland Report and has been expressed in a variety of ways over the years. Rogers (2006), for instance, quotes the existence of fifty widely used definitions. Perhaps the better-known (and widely contested) meaning of sustainability was given by the United Nation's Commission on Sustainable Development in 1987: 'to satisfy current needs without compromising the needs of future generations'. It defined sustainable development as "development which meets the needs of the present without compromising the ability of future generations to meet their own needs". Water resources projects are sustainable, if water of sufficient quantity and quality at acceptable prices is available to meet demands and quality standards of the region now and in the future without causing the environment to deteriorate (Plate, 1993).

The goal of environmentally sound and sustainable development of groundwater resources is to develop and manage them in such a way that the resource base is maintained and enhanced over the long term (Nwankwoala and Udom, 2008). The following key principles reflect different aspects of concern in the evolution of sustainability in groundwater development:

(a) Long term conservation of groundwater resources;

(b) Protection of groundwater quality from significant degradation; and

(c) Consideration of environmental impacts of groundwater development.

It was at the United Nations Millennium Summit held between $6^{\text {th }}$ and $8^{\text {th }}$ September 2000 at the United Nations Headquarters in New York, United States of America, that 189 Heads of State adopted the Millennium Development Goals (MDGs), which set clear, numerical, time-bound targets for making real progress by 2015 in tackling the most pressing issues facing developing countries. One of the goals of MDGs is to cut by half the proportion of people without sustainable access to safe drinking water and sanitation by 2015. The World Water Development Report (WWDR), states that the problems of poverty are inextricably linked with those of water - its availability, its proximity, its quantity and its quality. Improving the access of poor people to water has the potential to make a major contribution towards poverty eradication (Nwankwoala and Mmom, 2008; Nwankwoala, 2011; Idris-Ndah et al., 2014). The Millennium Development Goals Report (MDGR) of 2006 in Nigeria shows that there is a likelihood of achieving three of the eight goals in Nigeria; achieving universal basic education; ensuring environmental sustainability; and developing global partnership for development, while the health and poverty eradication MDG's remain daunting challenges for Nigeria.

The Obasanjo administration's constituency projects were conceived, planned, designed and implemented by the relevant federal Ministries, Departments and Agencies (MDAs), and sponsored by members of the National assembly, each of whom was actively involved in identification and siting of the scheme(s) in their individual constituencies. However, a radical departure from this in the Yar'Adua administration saw to the delegation of this responsibility to the office of the Senior Special Assistant to President for the Millennium Development Goals (OSSAP-MDGs) under the title "2008 Quick Wins MDGs (QW-MDGs) Projects". In order to improve project delivery and achieve higher success rates, the OSSAP-MDGs has elected to utilize the significant resource base of indigenous architectural, engineering and quantity surveying consulting firms to contribute to the efficient, honest and timely execution of the 2008 QW-MDGs projects.

It is no exaggeration that safe water supply underpins the achievement of most of the other MDGs. There can hardly be substantial human development without access to safe water; most classrooms will remain empty with pupils out looking for water, most hospital facilities will be stretched to the limit with people suffering preventable diseases as a result of poor water and sanitation facilities. Provision of water and sanitation should therefore be considered as the driving force of the poverty reduction programme of the government (Lee and Bellamy, 2009). One of the greatest contributions of water to the human development is health improvement and reduction in the time needed to search for water. It means that access to safe water will ensure the physical well-being of man and free his time for other activities and pursuits that will contribute to his economic freedom and that of the country at large, pupils will go to school on time, have time to read, women will have more time to be engaged in productive economic activities and infant mortality will be drastically reduced (Idris-Ndah, 2014).

The MDG's programme effectively commenced in Nigeria in 2005, meaning it was already five years late, also the country had not been fulfilling its financial commitment of one billion dollars annual allocation to its implementation. The QW-MDGs 2008 Projects was effectively expected to commence on the 27th August 2008 with the programme preparation/initializing phase and to be completed on 30th June 2009 with the programme wrap-up/completion activities. The programme, as shown by Idris-Ndah, (2014) has only attained between $60-70 \%$, completion with some sites even yet to be surveyed. Unlike other sectors which are mostly construction that involve just one or two professionals with others often being artisans, borehole drilling is a specialized operation that requires specialized machines/tools and experienced experts. The machines 
and tools must suit the local geology and professional expertise must be combined with experience of the driller for any meaningful success to be achieved. Most boreholes failed as a result of inadequate drilling machines and tools and lack of professional experience by the contractors who are local based.

The main objectives of the water supply programme are to provide expanded access to safe drinking water for Nigerians (especially rural and semi-urban residents), thereby reducing incidence of water borne diseases; and also to provide water for livestock and other uses thereby increasing food production. Implementation of the 2008 QW-MDGs programme involved a number of organizations interacting at different levels with the Federal Government being the main client. Others include the National Assembly (NA), the Programme Steering Committee (PSC), the MDAs, the National Management Consulting (NMC), the State Project Consultants (SPCs), and the Contractors / Suppliers.

The National Management Consultant (ETAT Consulting Ltd) oversees the contractor / supplier selection process through the tender process, prepares the project designs, bills of quantities and other operational guidelines. The NMC generally monitors and control the implementation of the project in accordance with the approved design, schedules and specifications, and within the agreed contract price. The National Steering Committee (NSC) is the body set up by the federal government to oversee the entire activities of the MDG's, the committee works in conjunction with the National Assembly and the Ministries, Departments and Agencies (MDA's) in determining projects to be carried out under the programme. The Office of the Senior Special Assistant to the President on MDG's (OSSAPMDG's) is the implementation arm of government that executes the projects determined by the NSC, this it does through the National Management Consultant (NMC) who in turn is responsible for State Project Consultants (SPCs) in each state. A critical barrier to planning for achievement of the MDG's continues to be the availability of up-to-date data on most of the indicators. This is compounded by the limited funding available for data generation and management. But more importantly, the push to improve water supplies through the MDGs is thus a great contribution in the fight to combat poverty.

\section{Efforts at Poverty Eradication in Nigeria}

The Third National Development (1975) focused on development; that development should prevail simultaneously in all geographical areas of the country and emphasized that lagging regions can no longer be tolerated. Rural development involves conscious efforts to contribute to the overall rate of economic growth and the process of structural and attitudinal transformation of rural areas (Enoh, 1991). Prior to the National Third Plan, the Fund for Agricultural and Industrial Development
(FAID) was established by Eastern Nigeria Government in 1963 to boost agricultural production. The South Eastern State Government established the Farmers Credit Schemes to grant loans to farmers and fishermen in 1972 (Ndaeyo, 1982). In 1973 the Federal Government created Agricultural Credit Guarantee Scheme Fund (ACGSF) mandating the Nigerian Agricultural and Cooperative Bank (NACB) to implement. In 1987, the Basins Loan Scheme, the National Livestock Development Project (NLDP) and the National Directorate of Employment (NDE) were introduced. Relatively recent were introduction of Directorate for Food, Roads and Rural Infrastructure (DFFRI), Better Life for Rural Women, Family Support Programme (FSP). Far back as 1976 was the period rural electrification first appeared in the development dictionary of Nigeria.

Groundwater is a 'very popular commodity' with farmers (Shah et al, 2007) since it is usually found close to the point-of-use (often only a well's depth away), can be developed quickly at low capital cost by individual private investment, is available directly on-demand for crop needs (given a reliable energy source for pumping) and thus affords small-holders a high level of control year-round, is well-suited to pressurized irrigation and high productivity precision agriculture, has 'democratized' irrigation by permitting irrigated agriculture outside canal command areas.

In developing and transforming nations the 'groundwater-irrigation boom' occurred at various economic levels (Garduno and Foster, 2010) - from subsistence farming to large-scale staple-crop production and commercial cash-crop cultivation. It has brought major socioeconomic benefits to rural communities and in many countries has helped to alleviate agrarian poverty through increasing food security - by ensuring water availability at critical times for crop growth and mitigating devastating effects of drought on crop yields (Shah, 2009). In South Asia the groundwater boom has also largely been pro-poor, with marginal farmers of holdings smaller than 2 ha increasing their groundwater-irrigated area by three times more proportionally than farmers with more than 10 ha of land.

Groundwater resources tend to be undervalued, especially where their exploitation is uncontrolled - when the resource exploiter (in effect) receives the benefits of groundwater use but (at most) pays only part of the costs - and this undervaluation often leads to economically inefficient resource use.

To improve agricultural returns to the rural poor some have suggested agricultural modernizations. Some argue that agricultural growth has led to broad based improvements in rural condition (Garha, 1988: Leaf, 1983; Barmum and Squinie, 1979; Ser, 1975; Randhawa, 1975). Others maintain that gains from rural modernization have not resolved labour and welfare problems (Otsuka et al., 1992; Ser and Grown, 1987; Raj, 1969) or that the benefits have been unfairly skewed 
toward richer farmers leading to increasing inequalities and inequalities in the countryside (Agarwal, 1986; Epstein, 1973; Frankel, 1971). Above all, government never considered qualitative and creative education as instrument that would reduce poverty. Even the 6-3-3-4 system, of which the first three years of a child's secondary education were to emphasize technical knowledge, was abandoned right from on-set.

Government's efforts in 2002 to reduce poverty led to strengthening the National Poverty Eradication Programme (NAPEP) and perhaps the strategy for implementation. Budgetary allocation to the core poverty eradication ministries and agencies totaled N132.47 billion, was pooled into the Poverty Eradication Fund (CBN, 2002). The source has it that a total of 2,497 threewheeler paggio cars called KEKE NAPEP, were sold to beneficiaries at subsidized rates in all states of the Federation.

Water is very essential for food production as well as essential for plant growth. Water is needed for seeds to germinate, seedlings to emerge and for many plant growth functions. When water for plant growth is controlled by irrigation, average yield under comparable climatic conditions are generally higher than those obtained under rain fed conditions. Because yield on irrigated lands are higher and more consistent, water plays an important role in food production. The everincreasing cost of foods in Nigeria is due to over dependence on traditional agriculture practice, which is mainly rain fed. Irrigation can help to increase food production if it is well embraced particularly where there is a general trend indicating decline in farming population.

Idachaba (1991) gave five reasons for national food insecurity. The two foremost reasons are (i) Nigeria's overwhelming dependence on rain fed agriculture which makes national food security highly vulnerable to vagaries of weather and (ii) the failure to increase the share of agriculture under irrigation. One of the major functions of the RBDA's is the development of irrigated agriculture. At inception in 1976 the RBDA's developed several schemes across the country which generated immediate benefits in terms of food production. Unfortunately, this laudable performance was short lived due mainly to problems of funding and management (Alatise, 2001).

\section{Water Security and Sustainable Democracy}

For a workable democratic ideology, a national policy on every infrastructure needs regional and local administration to ensure its implementation. A regional framework is necessary to ensure an integrated policy approach, bringing together economic, social and environmental objectives leading to more effective policymaking. The governments need to set up regional development agencies to provide assistance with implementation and establish an integrated basis to be able to overcome water crisis which will alleviate water security in the communities. But a degree of flexibility in planning and implementation will always be necessary, because what may be seen as sustainable in one region of the country is not necessarily the solution in another, but principles remain the same.

Government must be committed to an overall strategy that will aim at economic prosperity, raising standards of living for its people, protects and enhance accessibility to good potable water. At state levels, there must be a framework which adopts an integrated policy approach that is based on appropriate action through community participation. Any water management system requires the support of an appropriate governance framework. A bottom-up approach seems the best way to achieve participatory management. Surface water irrigation communities constitute a good example. Thus, top-down control has proven insufficient in most places due to this intrinsic complexity of groundwater governance. This is the reason why user communities are often advocated as the most plausible solution to ensure adequate groundwater resources management. Groundwater user associations are still fairly scarce. In any case, since groundwater user associations are a relatively new feature, their ultimate implications on groundwater sustainability are yet to be seen (Schlager and Lopez-Gunn 2006; Lopez-Gunn and MartinezCortina, 2006).

It is often considered that top-down infrastructural programmes are not sustainable and begins to fold immediately after commissioned. If such are the reasons, the governments of the day need to be committed to the fundamental requirement thereby initiating dynamic bottom-up initiatives and approaches. Successive governments in Nigeria should continue to maintain and improve on the ongoing projects established by their predecessor. In this concept, Dun-Gwom (1999) based good democratic governance of resources on management which deals with the effective care, prudent use of and conservation of resources to meet present and future needs of man in maintaining a good quality of life. The concept of partnerships as a model for planning and management of water resources in the 21 st century is appropriate and advocated.

According to Ayoade and Oyebande (1983); Nwankwoala and Mmom (2008); Nwankwoala (2009), there is relationship between water availability and economic development in Nigeria. Availability of water is one of the factors controlling the distribution of population in Nigeria. Webb and Iskandarani (1998) defined water security as an access by all individuals at all times to sufficient safe water for a healthy and a productive life. Water security is the absolute quality and quantity of water reliably supplied to perform cultural normal life (Thomas, 1998). Water supply is however so important that no government can wave it off among the services to be rendered to the citizens. Indeed, there is no welfare service that impinges more closely upon the daily life of 
the people or that more readily arouse peoples interest than water. It was the recognition of the importance of water supply that led to the passing of a resolution emphasizing the need for potable water supply before the year 2000 at the United Nations Habitat Conference in 1976. Consequently, water security is the pivot on which democratic principles can be aligned for appropriate development (Ibbi and Timothy, 2012).

\section{Groundwater Accessibility}

Reliability and accessibility of data, especially data on "informal" access to water for various purposes such as agricultural (livestock and crop production) and smallscale industrial uses are almost non-existent, and certainly not systematized. Access to water is a basic human right, but for many of Nigeria's poor, water is only available at a price, and supplies are often not safe. The human cost of lack of access to safe water is huge, reflected in the high child mortality rates (UNICEF, 2006).

Poverty is a multi-dimensional experience of a large number of men, women and children in Nigeria, especially in rural areas. It is not simply a matter of having a low or irregular income, but of lacking a wider set of assets (human, social, physical, natural as well as financial), and being vulnerable to changes which the less-poor can more readily survive.

Poverty is understood to be more complex and multidimensional than simply a lack of income, reflecting both severity (depth below the absolute poverty line of $\$ 1$ a day) and duration of poverty (CPRC, 2005). The push to improve water supplies through the Millennium Development Goals is thus a great contribution in the fight against poverty. The Millennium Development Goal 7, Target 10 concerns increases in coverage of water supply - serving the un-served. This means more sources, more construction, and more capital investment. Achieving higher coverage through groundwater development requires better hydro-geological understanding for improved siting, reduced construction costs, and increased overall investment. The chronic poor (below the poverty line for 5 years or more) are naturally the most vulnerable in terms of security and survival - when disasters such as drought strike, they have the least protection. Long-term support that is able to lift people out of chronic poverty must reduce vulnerability and improve chances of survival.

The sustainable livelihood concept (Carney, 2003), provides a helpful integrated conceptual framework for understanding poverty. Poverty needs to be understood from the point of view of the poor. Groundwater's potential contribution to the enhancement of livelihoods and poverty reduction is great, although not without challenges and gaps in our existing understanding. One opportunity is the reduction of the costs of conventional (mechanized) drilling and a Second, development, promotion and uptake of very low-cost well construction techniques through indigenous small-scale private enterprise (Carter and Bevan, 2008).

Reducing conventional drilling costs requires significant changes in the practices of public and private sector institutions and donors. But, because of inherently high cost of drilling, it is essential that a far higher proportion of new boreholes continue to function and serve their users than at present. This requires better knowledge of groundwater recharge, enhanced construction quality, and more effective practices for borehole and pump operation and maintenance.

Very low cost (manual) drilling techniques range from the traditional (Asian sludging, hand percurssion) to the modern (auguring, jetting), with numerous variants. The approaches for accessing groundwater can be hinged on the aforementioned technologies and need to be fashioned and modified to the needs of the users (Carter and Bevan, 2008):

(i) Externally-driving approaches to poverty alleviation in general, and groundwater development in particular, have made significant progress in extending people's access to water. Technical solutions in which the users typically contribute less than $10 \%$ of the capital cost, and in which insufficient time is set aside to bring about full community participation and management, suffer major problems of lasting maintenance and functionality. The almost exclusive use of externally-driving approaches in Sub-Saharan Africa in general, and in Nigeria in particular has led to an aid-mentality in which people often wait for governments or NGOs to act for them, and are reluctant to take initiatives for themselves. There is need to apply all possible measures to instill local ownership and responsibility (including financial responsibility) for operation and maintenance, and to ensure appropriate on-going support or check-stopping is available. However, in cases where there is no other option than that of deep or hard rock drilling, then externally-initiated solutions, using mechanized drilling are necessary.

(ii) Self-initiated approaches (also known as self-supply) are alive and well. Interventions to support such local initiatives offer significant promise, as they build on people's own attempts to solve their water problems, thereby enhancing ownership and the potential for longterm sustainability.

(iii) Enterprise-response to user-demand approach combines technology innovation, small enterprise development, and market stimulation (or demand creation), to provide locally sustainable solutions to the water problems of farmers, households and communities.

The technology innovation, existing technologies (hand percussion, hand augering, sludging, jetting and their variants and combinations) need to be modified and adapted to local geological and economic environment. Particularly, equipment needs to be manufactured locally from readily available parts and components (e.g. standard pipes and fittings, flexible hose, timber, rope, 
centrifugal pumps), and using simple fabrication technologies (e.g. cutting, hardening, welding, threading). On the other hand, small enterprises need to be introduced to "new" technologies, trained in their use, and then provided with business training. They may need additional support in kind (e.g. equipment, transport) or in cash (seed capital or credit) in the short-term, as well as longer term assistance until they become viable business entities. The development of the market refers to both demand creation among potential water user (who may also require short -term credit facilities to access the technology), as well as assistance with market linkages for the output of productive water uses, especially crops.

The greatest possibility for poverty reduction in Nigeria would appear to lie in the application of these technologies through small enterprises developed or strengthened to deal directly or indirectly with households, farmers, communities and institutions. There are signs of hope, not least in the growth of indigenous entrepreneurship, and in the growing number of case studies of successful development of groundwater for poverty alleviation in Sub-Saharan Africa region.

Underlying the issues highlighted are several weaknesses which are challenging:

- Resistance in the public sector which professionals experience when they try to change design standards or practices;

- Limited expertise, and even more limited resourcing, at local government levels to permit adequate contract management and supervision;

- Difficulties for the indigenous private sector of "doing business" - obtaining loans on realistic terms, importing of spare parts and consumables, competing fairly in a transparent operating environment, and having some assurance of a sufficient workload;

- Insufficiently detailed knowledge of groundwater conditions, introducing uncertainties into contract specifications;

- Unacceptably high post-construction failure rates.

In order to reduce the cost of conventional drilling, the following considerations are very necessary:

- Better sitting, lower cost designs, use of smaller rigs, packaging of contracts, higher quality supervision and contract management;

- Long-term training and capacity building in hydrogeology, construction supervision, contract management and drilling;

- Commitment, leadership and quality of management at highest level in relevant public sector authorities and private companies.

\section{Groundwater Supply Sustainability for lasting Poverty Reduction}

Water constitutes the most important resource to man.
The domestic requirement of water varies with the level of economic development of an individual. According to Gleick (2001) an overall basic water requirement of 50 litres of water per person per day as a minimum standard is required to meet four basic needs (drinking, sanitation, bathing, and cooking). The amount of water that people use does not depend only on minimum needs and how much water is available for use but on the level of economic development and extent of urbanization shouldering around democratic advancement. Freshwater demand per capita is rising substantially as countries develop economically. Withdrawals of water have grown tremendously beyond meeting the rising industrial demand, domestic demand and reliance of irrigation to produce of food (Biswas, 1992). The level of water use reflects the level of urbanization in a country. Low household water use in developing countries today reflects difficulty in obtaining freshwater. Majority of people in developing countries get their water from public standpipes, community wells, rivers and lakes, or rainfall harvested off roofs. Water security in this aspect, is not only a commodity but also a natural resource and a perceived human entitlement (Rosegrant, 2001). Water ranks higher than any other infrastructure in the survival and welfare of humanity.

A distinction must be made between developed and developing regions. Today, about one thousand million people live under the poverty threshold (i.e. those people who make a living with less than one dollar per day; whereas another two and a half thousand million make less than two dollars per day) (Llamas, 2005). While access to drinking water is often said to be related to poverty, very few studies show the potential importance of groundwater resources in reaching another of the United Nations Millennium goals: halving the number of people who suffer from malnourishment by 2015.

However, groundwater is already playing a key role on that front. Take for instance India, where groundwater irrigated surface has increased by over forty million hectares during the last decades (Deb Roy and Shah, 2003). Largely as a consequence, India has not only achieved food security in practice, but has also become an important grain exporter, all these despite doubling its population in the last half century. This is an example of the 'more crops and jobs per drop' motto, which groundwater is generally more likely to achieve than surface water irrigation (Hernandez-Mora et al., 2001). However, this is not necessarily applicable in developed countries, where 'more cash and environment per drop' is probably more in touch with reality.

On groundwater use and social sustainability, groundwater irrigation has proven an excellent catalyst for the positive social transition of farmers in arid and semiarid regions worldwide (Moench, 2003; Steenberger and Shah, 2003). This is largely a consequence of groundwater's resilience against drought. Secured access to water during dry periods removes a sense of 
risk from farmers' minds. Thus, they are more willing to invest in new technologies, both from the agricultural (selective seeds, agrochemicals) and the technical point of view (drip irrigation). This results in increased revenues and allow for a greater degree of social welfare. In addition, farmers become able to provide a better education for their children, who may either move on to other economic sectors or return to agriculture with a more productive outlook. Issues of social justice may arise in some situations. For example, in some areas of India, deep boreholes drilled by wealthier farmers have caused the water table to drop below the reach of shallow wells, which are generally owned by the less resourceful (Moench, 2003). However, this seems to be a transitory state. In fact, rich farmers end up selling excess water to shallow-well owners. Since supply is seemingly large enough to ensure a competitive market, the less resourceful have access to water at reasonable prices. This allows them to continue making a living out of irrigation, while getting wealthier in the process. After a few years, poor farmers have been able to drill their own deep wells (Mukherji, 2006; Mukherji and Shah, 2006).

\section{Groundwater Resources: Future Perspectives}

In Nigeria water resources, including rain harvesting, surface water and groundwater are obtainable in varying quantity from place to place. The least of these is the groundwater source, yet it is the most abundant, most reliable and cheapest to harness. While access to drinking water is often said to be related to poverty, very few studies show the importance of groundwater resources in achieving the United Nations Millennium Goals: halving the number of people who suffer from malnourishment by 2015 (Llamas, 2005). Groundwater is already playing a key role in meeting the MDGs. Groundwater irrigated surface has increased by over forty million hectares during the last decades (Deb Roy and Shah 2003). Largely as a consequence, Nigeria can achieve food security in practice and become an important grain exporter. Groundwater irrigation has proven an excellent catalyst for the positive social transition of farmers in arid and semiarid regions worldwide (Moench, 2003; Steenberger and Shah, 2003). This is largely a consequence of groundwater's resilience against drought. Secured access to water during dry periods removes a sense of risk from farmers' minds. Thus, they are more willing to invest in new technologies, both from the agricultural (selective seeds, agrochemicals) and the technical point of view (drip irrigation). Increased revenues result, and allow for a greater degree of social welfare. In addition, farmers become able to provide a better education for their children, who may either move on to other economic sectors or return to agriculture with a more productive outlook.
Groundwater education appears a must, not only aiming at high-level water decision-makers, but also at the general public and more importantly to farmers (generally the main groundwater users and polluters). Generally speaking, water managers and decisionmakers have traditionally been trained to build and operate large surface water infrastructures. As a result, the importance of groundwater resources is often overlooked or even disregarded. This may provide an explanation for the generalized lack of accurate groundwater data. Besides, it appears to be the reason of the huge gap that currently separates water decisionmakers from the main actors. Last, but not least, corruption is increasingly recognized as a potential 'cancer' for democratic systems (OECD 2000; United Nations, 2003). Water resources are not an exception. As stated by the Valencia Declaration (Sahuquillo et al., 2005), groundwater is less prone to corruption than large surface water infrastructures. This obeys two main reasons. First, implementation of groundwater development presents a comparatively shorter timeframe (often weeks or months in comparison with several decades taken to implement a surface water system based on dams and canals). Second, investments in groundwater development are generally much smaller, and usually carried out by individuals with little or no public funding. In contrast, large surface water infrastructures frequently require significant public subsidies or donations from international organizations. This setting (long implementation time, significant funds) allows more room for unethical practices.

It is extremely difficult to provide a 'general guide to groundwater sustainability' as complying with the dimensions may not be possible in most cases. Emphasis on one or another is likely to depend on economic, social, cultural and political constraints. Groundwater management requires a higher degree of user involvement than surface water developments. Experience shows that sustainable aquifer use cannot be solely achieved by means of top-down "control and command" measures. A frequently quoted aspect of 'sustainability' is that the potential future needs should be born in mind before launching into any development. In other words, the current generation should strive to preserve the world's natural resources so that coming generations may be able to take advantage of them.

User participation requires a degree of hydrogeological education which is still absent in most places in Nigeria. Steps should be taken to make the peculiarities of groundwater resources known to all, from politicians and water decision makers to direct users as well as the general public. This should begin at the school level. Appropriate groundwater management requires a significant degree of trust among stakeholders. This implies that groundwater data should be transparent and widely available (via the internet, for instance). In 
addition, the system should be able to punish those who act against the general interest.

Existing groundwater data is often scarce or laden with uncertainty. This is largely a consequence of the relative novelty of intensive groundwater development, a phenomenon that has only become commonplace in the last four or five decades. Secondly, intensive groundwater use has been often carried out with little or no planning or control on the part of public water agencies, leading to chaotic development in most cases. Causes should be found in the historical past: for thousands of years (although more particularly in the 19th Century), water managers and decision makers have been trained to build and operate surface water infrastructures, while 'invisible' groundwater resources have received less attention. On the other hand, the private initiative has traditionally been the main driving development, particularly in arid and semiarid regions where irrigation is necessary for agriculture. Millions of farmers, modest for the most force behind intensive groundwater part, today drill their wells and pump groundwater at their own expense. Uncontrolled drilling and pumping has led to problems in some places. While some of these constitute an undeniable matter of concern, the majority have been magnified due to ignorance, institutional inertia, vested interests and corruption.

\section{CONCLUSION}

The Nigerian nation need to appreciate the scale of their social, economic and environmental reliance on groundwater to invest in strengthening efforts to improve scientific understanding, and to develop governance systems and management institutions before substantial portions of the groundwater resource are degraded. This is vital to assure and sustain the improvements in human livelihoods, food security and poverty alleviation/reduction and if further progress is to be made towards achieving water- dependent targets within the Millennium Development Goals. A functional sustainability of groundwater development requires better understanding of the renewable resources involved (i.e. groundwater recharge), improved construction supervision practices, and efficient maintenance, repair and rehabilitation arrangements for pumps and boreholes.

Groundwater supplies have found to be very feasible and the most economic source of potable water for rising rural population. Groundwater resources - the guarantee of a sustainable future has fallen noticeably behind in basic issues as education (both formal and informal) about water use, knowledge of the characteristics of groundwater resources, efficient public policies, the presence of the government as a controlling entity of the social use of water, together with a growing pauperization of the population and a lack of user participation in the management of resources. Quite unfortunately, in spite of the fundamental role groundwater plays in human wellbeing, as well as that of many ecosystems, it is yet to be fully appreciated and adequately managed and protected, both within the country and regionally. The government policy should be aimed at eradicating water borne and water related diseases in the rural areas in order to raise a healthy and more productive people.

The provision of groundwater supplies for agriculture and cottage industries will raise the rural standard of living and reduce poverty. It is a well-known fact that groundwater basins are difficult to govern and manage, partly because of poor information, and also because of poor visibility of the resource, the need for reliable data and accurate information and appropriate expertise in support of water resource planning is central to any strategy. To this end, there is a serious need to strengthen groundwater-related research and educational programs. Monitoring of groundwater resources of the country in quantity and quality should also be pursued as integral component of the various water resources development programs and projects. Poverty causes lack of regard for constituted authority as it breeds hunger, social rejection and dejection, and at the extreme case, armed robbery. The issue of poverty alleviation should be taken with all amounts of seriousness it deserves and not ordinarily paying lip-service to it. Therefore, the suggestions advocated in this paper, if sincerely implemented, have the potential of reducing poverty in Nigeria. More importantly, special attention should be given to improving knowledge and assessing the total benefits and costs of using groundwater to alleviate poverty.

\section{REFERENCES}

Agarwal B (1986). Women, poverty and agricultural growth in India. J. Peasant Stud., 13(4): 1927

Asian Development Bank (ADB), (1999). Fighting poverty in Asia and the pacific. The Poverty Reduction Strategy of the Asian Development Bank, Manila.

Ayoade JO (1988). Tropical Hydrology and Water Resources; an Introduction to Hydrology, University of Ibadan. Nigeria.

Baker J (2000). Evaluating the impact of development projects on poverty: A handbook for practitioners. Washington, D.C. World Bank.

Barmum HN, Squinie L (1979). A model of an agricultural household: Theory and evidence. World Bank Occasional Papers No. 27, The John Hopkins University Press.

Burkey S (1993). People First, A Guide to Self-reliance, Participatory Rural Development. Zed Books Ltd., London.

Carney D (2003). Sustainable Livelihoods Approaches: Progress and Possibilities for Change. DFID, London

Carter RC, Bevan JE (2008). Groundwater Development for Poverty Alleviation in Sub-Saharan Africa. In: Adelana, A; MacDonald A Abiye TA, Tindimugaya C. Applied Groundwater Studies in Africa (Eds.) IAH Selected Papers on Hydrogeology, CRC Press. A Balkema Book. 13: 25 - 42

Central Bank of Nigeria, CBN, (1999). Infrastructure Expenditure Policy and Private Sector Output in Nigeria (1970-1998).

Central Bank of Nigeria, CBN, (2002). Central Bank of Nigeria Annual 
Report and Statement of Accounts, 31st December.

Central Bank of Nigeria, (CBN) (1999). "Nigeria's Development Prospects: Poverty Assessment and Alleviation Study," CBN, Lagos, 1999.

CPRC (2005). The Chronic Poverty Report. Chronic Poverty Research Centre, Manchester, UK.

Das-Gupta A, Puspa RO (1997). Sustainable groundwater resources development, Hydrological Sci. J. 42(4):565-582

Dun-Gwom JY (1999). Partnerships in Planning and Environmental Management in Nigeria; in J. Environ. Sci. Published by Faculty of Environmental Sciences, University of Jos, Nigeria. 3:1 and 2.

Ekong CN (1997). Frameworks for building sustainable strategies in Nigeria. NES Proceedings.

Ekong EE (1991). Rural development and the persistence of poverty. University of Cross River State, Uyo, Inaugural Lecture Series, No. 1 , June.

Enoh COE (1991). Applying the Objective Possibility Model to the Development of Rural Areas in Countries: The Case of Akwa Ibom State of Nigeria. In: Ukpong, I.I. and P.U. Iniodu (Eds.), Priorities for the Development of Akwa Ibom State, CDS, University of Uyo.

Epstein TS (1973). South India Yesterday, Today and Tomorrow. Holmes and Merer, New York.

FGN (1980). Third National Development Plan, Federal Government of Nigeria.

Frankel F (1971). India's Green Revolution: Economic Gains and Political Costs. Princeton University Press, Princeton.

Garha R (1988). Income mobility in rural India. Econ. Dev. Cult. Change, 36(2): $23-28$

Gleick PH (2001). The Changing Water Paradigm: A Look at TwentyFirst Century Water Resources Development, Water International, 25(1):127-138.

Guntur S (2007). Poverty Impact Analysis: Approaches and Methods. In: Guntur, S. (Ed.), Poverty Impact Analysis Selected Tools and Applications, Asian Development Bank.

Ibbi IS, Timothy N (2012). Water Security and Good Governance in Niger State of Nigeria: Challenge for Sustainable Development, Transnational J. Sci. Technol. 2(8): 68- 78

Idachaba FS (2000). Topical Issues in Nigerian Agriculture: Desirable and Workable Agricultural Policies for Nigeria in the First Decade of the 21 st Century. Department of Agricultural Economics, University of Ibadan.

Leaf MJ (1983). The green revolution and cultural change in a punjab village. Econ. Dev. Cult. Change, 31(2).

Moench M (2003). Groundwater and Poverty: Exploring the Connections, In: Llamas M.R and Custodio, E (Eds) Intensive Use of Groundwater: Challenges and Opportunities. Swets and Zeitlinger. The Netherlands.

Ndaeyo I (1982). How to make the basin loan scheme to succeed: A brief on the basin loan scheme. Presented to the Cross River Green Revolution Committee, Ministry of Agriculture, Nov., 30.

Ndebbio JEU (2006). The Structural Dimensions of Underdevelopment. Associated Vicissitudes and Imperatives: Agenda for Positive Change, 33 Inaugural Lecture, May 2nd, University of Calabar, Calabar.

Ndem AN (2008). Poverty to Sustainable Development (A Communitybased Approach). University of Calabar Printing Press, Calabar, Nigeria.

Nwankwoala HO, Mmom PC (2008). Groundwater utilization versus millennium development goals: Implications for sustainable development. J. Nig. Environ. Society (JNES). 4(3):34 - 42

Nwankwoala HO, Udom GJ (2008). Groundwater protection as viable option for sustainable water supply in Nigeria. Global J. Geol. Sci. 6(2):153- 156.

Nwankwoala HO (2009). Groundwater development and management in Nigeria: mission achievable or mission impossible? Water Resources Journal of the Nigerian Association of Hydrogeologists, 19:63-68

Nwankwoala HO (2011). An integrated approach to sustainable groundwater development and management in Nigeria. J. Geol. Min. Res. (3)5: $123-130$.

Organization for Economic Co-operation and Development (OECD). (2000). "No more business as Usual: Fighting Bribery and Corruption" Paris. pp 275

Otsuka KV, Cordorra, Christiana CP (1992). Green Revolution, Land Reform and Household Income Distribution in Philippines. Econ. Dev. Cult. Change, 40(4): 1965-2018.

Raj KN (1969). Some questions concerning growth: Transformation and planning of agriculture in developing countries. J. Dev. Plan., No.

Randhawa MS (1975). Green Revolution in Punjab. Punjab Agricultural University, Dudhiana.

Ser G, Grown C (1987). Development Crisis and Alternative Visions: Third World Women's Perspective. Monthly Review Press, New York.

Ser S (1975). The Green Revolution: Food and Jobs for All. McGraw Hills Publishing Co., New Delhi.

Shiklomanov IA (1998). World Water Resources - A New Appraisal and Assessment for the $21^{\text {st }}$ Century, UNESCO, Paris.

World Bank (1991). The Reform of Public Sector Management: Lessons from Experience. Washington D.C

\section{How to cite this article:}

Nwankwoala. Groundwater and Poverty

Reduction: Challenges and Opportunities for

Sustainable Development in Nigeria. Int. Res.

J. Geol. Min. 6(2):028-037 